\title{
LEGAL AND PRACTICAL ASPECTS REGARDING THE DEVELOPMENT OF THE ROAD SAFETY AUDIT IN ROMANIA
}

\author{
Lucian Ioan TARNU \\ lucian_tarnu@yahoo.com \\ “LUCIAN BLAGA” UNIVERSITY, SIBIU, ROMANIA
}

\begin{abstract}
Road safety, security and prevention of accidents in road traffic are both a national and international priority. Each road user should have an important and active role, thinking of both his own safety and about the danger he poses to the other participants' safety through his behavior in traffic.
\end{abstract}

\section{KEYWORDS:}

Audit, road safety, road accident, vehicle, control

1. General aspects regarding the principles, purpose, objectives, development and effects of the audit process

Road safety is viewed and must be addressed to as a matter of road transportation system because road accidents suppose direct costs incurred by health and business sectors and the families of those involved as well.

Road safety in completely in line with both the constitutional principle regarding people's free movement in country and abroad and the provisions of the Penal Code of Romania (art 339) by transfering the contraventions against the road safety pon public roads from G.E.O. 195/2002 to the Penal Code.

Despite some positive trends, road safety is still a big challenge in Romania, our country being among the four E.U. countries along with Latvia, Bulgaria and Lithuania that have the highest rate of accidents with victims.

In addition to programs and projects to prevent and combat the causes of road accidents, we believe that we should pay special attention to all policies aimed at more effective enforcement of legislation, improvement of the legislative framework and road regulations, improvement of road infrastructure and application of best practices in road safety at the European and international level.

The concept of "road safety audit" appeared around 1980 and developed in the UK. This concept aimed at improving operational safety within road projects (Tarnu, 2016).

Ten years later, the concept of road safety audit was introduced in Australia and also approved in the United States. In 1996, the Federal Road Administration, after having organized a tour in Australia to analyze the process, developed a number of pilot projects in 14 different countries.

Recognizing the utility and importance of audits in Pennsylvania, in 1997, the USA implemented the first road safety audit of this type. 
The development of road safety audit procedure is due to Malcom Bulpitt, UK, who, in 1980, used an audit model based on the concept of the independent audit in order to improve operational safety within road projects.

In 1990, in the UK, it was published the document called the "Guidelines for Road Safety Audit" and, in April 1991, the Department of Transportation adopted the audit process.

In 1994, in Australia, the AUSTROADS published the guide called the "Road Safety Audit" and, in 2002, a revised edition of it. The latter edition offered guidance for the road safety authorities from several countries.

Later on, road safety audits spread to New Zealand, Denmark, Iceland, Norway, Canada, France, Holland and Germany.

AUSTROADS (2002) defines road safety audit as "a formal examination of existing or future streets, or a traffic project or any work that interact with road users, within which a qualified and independent audit team reports the probability of road accidents and the performance level of road safety".

Among the objectives set by AUSTROADS (2002), we mention the following:
- Reduce the occurrence of collisions on the roads;

- Get road designers and traffic engineers aware of the importance of safety audit:

- Reduce the need for costly remedial work and reduce total costs.

So, the goal of road safety audit is to increase road safety and security before the projects may be implemented and road accidents occur.

Safety audits are usually compared with the analysis of road safety. The table provides a detailed compared analysis of the differences between the analyses of road safety and road safety audits. In fact, both procedures aimed at preventing the occurrence of collisions, but road safety audit is more formal and more comprehensive than the analyses of safety, focusing more on compliance with existing design standards. However, the compliance with safety standards does not guarantee the security of a project, because some errors are often overlooked. The standards cover the general and common situations and not all cases (Tarnu, 2016).

Therefore, safety issues can be solved by technical studies included in the audit procedure for road safety. These studies are more effective than just using standards.

Table no. 1

Comparison between road safety analyses and road safety audits

\begin{tabular}{|c|c|}
\hline Analyses of road safety & Road safety audits \\
\hline $\begin{array}{l}\text { - use a small team of one or two persons for } \\
\text { project expertise; } \\
\text { - the team members are usually involved in } \\
\text { the design; } \\
\text { - field tests are not usually included in the } \\
\text { safety analyses; } \\
\text { - focus on the evaluation of projects, based on } \\
\text { compliance with the standards; } \\
\text { - normally, do not take into account human } \\
\text { factors issues, including drivers errors, } \\
\text { visibility, etc.; }\end{array}$ & $\begin{array}{l}\text { - use a multidisciplinary team of three and } \\
\text { five persons; } \\
\text { - audit team members are independent } \\
\text { persons who are not part of the project; } \\
\text { - field tests are a necessary component; } \\
\text { - use checklists to analyze the particularities } \\
\text { of the project; } \\
\text { - are comprehensive and try to consider all the } \\
\text { factors that contribute to accidents; } \\
\text { - the needs of pedestrians, cyclists, heavy } \\
\text { trucks, and car drivers are taken into } \\
\text { account; }\end{array}$ \\
\hline
\end{tabular}




\begin{tabular}{|l|l|}
\hline \multicolumn{1}{|c|}{ Analyses of road safety } & \multicolumn{1}{c|}{ Road safety audits } \\
\hline- focus on the needs of road users; & - safety audits are proactive. \\
- analysis of safety is reactive. Dangerous & $-\begin{array}{l}\text { the locations prior to the development of } \\
\text { accident patterns are taken into account in } \\
\text { locations are identified by analyzing } \\
\text { accident statistics or observations, taking } \\
\text { corrective measures. }\end{array}$ \\
\begin{tabular}{l} 
occur. \\
\hline
\end{tabular}
\end{tabular}

General principles, the basis of road safety audit, are as follows:

1. The prevention of road accidents; the independence of the audit team towards the investor, designer and / or contractor of the project which is the subject of audit;

2. the respect of applicable regulations and the best international practices in force.

Road safety audit assesses the way of design and operation of roads, focusing on how it affects their safety in relation to road users such as: drivers, pedestrians, cyclists, motorcyclists and others.

Road safety audit is used in the following situations:

a) the stage of design and construction of new road sections; b) during the rehabilitation and modernization of an existing road;

c) in other works to improve the road infrastructure (the modernization of some roads, the rehabilitation of junctions, highways, bridges) and to avoid of "dangerous point".

The purpose of audit is to identify and, thus, to examine the potential of road accidents linked to the fulfillment of performance criteria of the road in point of road safety (Tarnu, 2016).

The main general objectives of road safety audit are presented in the following figure:

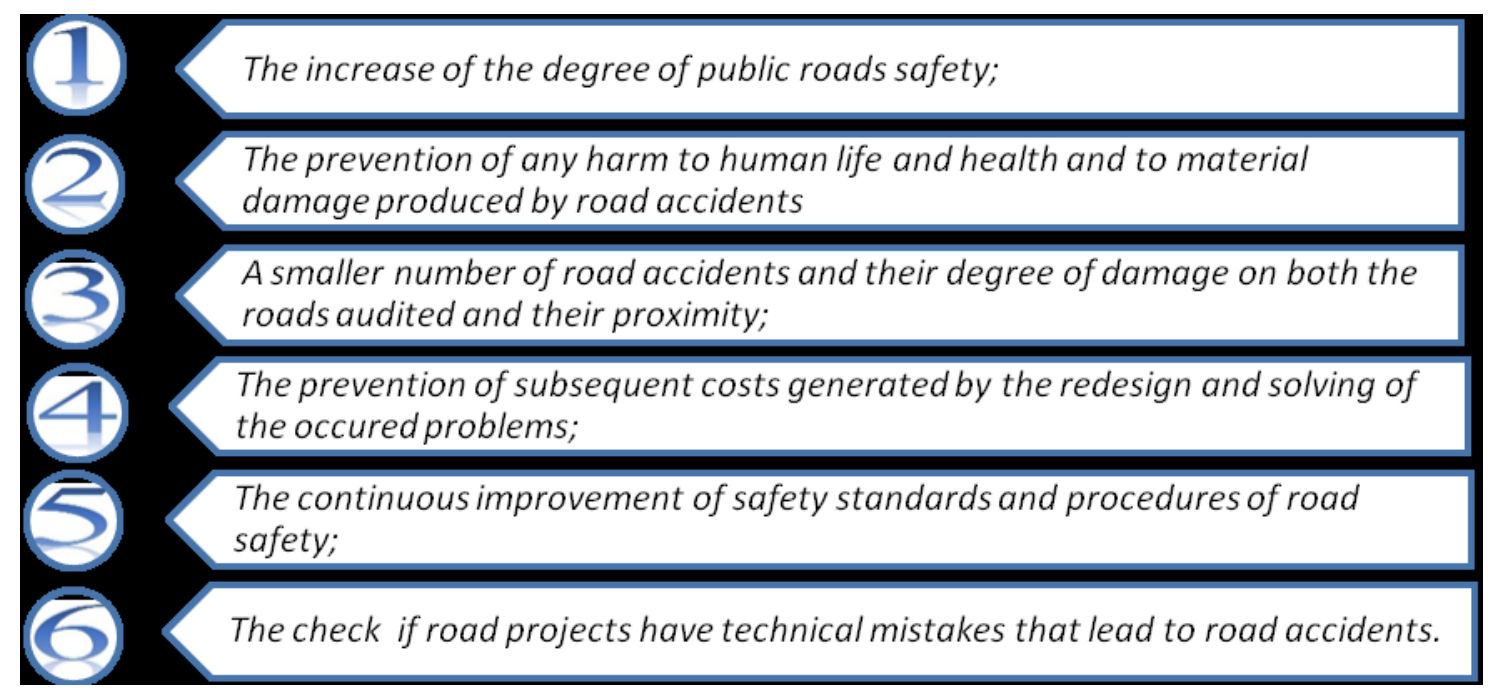

Figure no. 1 The main general objectives of road safety

Road safety audit is not a means of evaluation, criticizing the work of design. It does not replace the control of quality project, the check of compliance of project with standards or programs of road safety assessment.
To develop the audit, the audit team must be provided by the designer and contractor with the project design, drawings, maps and other information necessary for the optimal use of road safety audit. 
The visit on the site aims to visualize and analyze the interaction of the project with the surroundings and neighborhood routes from the road users' perspective and anticipate possibly occurring problems. Thus, the team members put themselves in place of drivers, pedestrians, bicyclists in order to identify all safety issues.

The usage of checklists is a valuable tool that can be used during both the control on the site and the audit meetings.

RISK $=$ Frequency of accidents $\mathrm{x}$ Degree of damage

FREQUENCY OF ACCIDENTS =

Probability x Exposure

The concept of risk is used in order to prioritize the measures that must be implemented in order to prevent road accidents by combating their causes.

Road safety audit is a written and detailed report addressed to the beneficiary and it consists in the following issues:

1. Deficiencies of road safety that were observed during the audit;

2. Recommendations to repair the deficiencies.

The beneficiary decides on the implementation of the recommendations stipulated in the audit report, providing in writing the audit and designer with the motivations and observations.

Among the effects of road safety audit, we can mention the following: "preventing road accidents; reducing the degree of damage of road accidents; reducing the subsequent costs in order to repair roads; providing easy road traffic in certain places; increasing the safety of road users by rehabilitation of some junctions" (Tarnu, 2012).
2. Practical compared aspects regarding the application of road safety audit in Romania

The research in the sector of road safety should offer the framework of making decisions regarding the safety policy so that a scientific approach can be applied to this issue.

The countries with the best international records in point of road safety are those which have traditionally the best institutions and the most active programs of research in the field of road safety.

It is important that Romania learns from other the E.U countries and to use their experience and ability of research so that, in the future, our country has the possibility to implement more efficient interventions of road safety.

At present, Romania does not have either a national strategy for research regarding road safety or an independent organization of research in the field of national road safety, but only demonstrative, pilot and limited programs regarding road safety. So, in Romania, there is no systematical research on the factors that are relevant in the sector of road safety for the following: vehicles, road infrastructure, human factors; institutional factors, other factors. Fortunately, after many years, in 2016, it was adopted the National Strategy of Road Safety for the period 2016-2020.

The research of road safety is not comprised in the sectors/sub-sectors of smart specialization of Romania that are part of the National Strategy for Research and Development. So, the chances to attract reimbursed funds for research in the field of road safety are limited. In spite of all that, Romania has more infrastructures of research and development integrated in the international research networks (i.e: ERRIS platform), by universities, institutions of research and development or private companies that have interests in the field, which offers the premises of some projects of research developed in collaboration with 
European partners. In this sense, an opportunity is the Horizon 2020.

In Romania, the Law no. 265, November, $7^{\text {th }}, 2008$, republished, regarding the management of road safety applied to road infrastructure, sets the institutional framework and the way of managing road safety. This law gets the provisions of the Directive no. 2008/96/EC of the European Parliament and of the European Council from November, $19^{\text {th }}, 2008$ regarding the management of road safety infrastructure.

According to this (point 2 from the annex I), the Minister of Transportation is the competent authority for regulation and control in order to apply the herein law.

According to the lawmaker, the purpose of this law is to assure, increase the degree of public road safety, prevent people's death and harm and avoid the damage generated by road accidents (Art. 2).

The Road Authority in Romania R.A.R. is the only institution that is competent to make the road control and manage the evaluation of the impact on road safety, of road safety audit and training activities, certification and professional updating of road safety authorities.

As far as its activities are concerned, the Road Authority in Romania achieves the main responsibilities regarding the management of road safety applied to road infrastructure.

The Road Authority in Romania also has other responsibilities stipulated in this law and other legal norms regarding road safety.

\section{Activities of the road safety audit}

Table no. 2

\begin{tabular}{|c|c|c|}
\hline $\begin{array}{c}\text { Evaluation of impact on } \\
\text { road safety, road safety } \\
\text { audit and controls of road } \\
\text { safety }\end{array}$ & The road safety audit & The control of road safety \\
\hline $\begin{array}{l}\text { Evaluation of } \\
\text { impact on road safety is } \\
\text { part of prefeasibility study } \\
\text { or feasibility study of a } \\
\text { project of road } \\
\text { infrastructure that can be } \\
\text { substantially modified. This } \\
\text { evaluation is made } \\
\text { according to the provisions } \\
\text { of the annex no. } 1 \text { of the } \\
\text { Law no. } 265 / 2008 \text { and it is } \\
\text { a report of evaluation of } \\
\text { impact on road safety. } \\
\text { The report of } \\
\text { evaluation of impact on } \\
\text { road safety must mention } \\
\text { the considerations in point } \\
\text { of road safety that have an } \\
\text { important role in choosing } \\
\text { the proposed solution and } \\
\text { provide all the relevant }\end{array}$ & $\begin{array}{l}\text { The road safety } \\
\text { audit is part of a project } \\
\text { of road infrastructure. It } \\
\text { is a report of road safety } \\
\text { audit and that must be made } \\
\text { on chapters according to } \\
\text { each stage (art. 10, para. } 3 \\
\text { of the Law no. 265/2008): } \\
\text { a. feasibility study/ } \\
\text { documentation of certifying } \\
\text { the intervention works; } \\
\text { b. technical project and } \\
\text { execution stages; } \\
\text { c. prior to the reception of } \\
\text { the public road in } \\
\text { question; } \\
\text { d. immediately after the } \\
\text { public road for traffic is } \\
\text { functional. }\end{array}$ & $\begin{array}{l}\text { The control of road } \\
\text { safety must be made for } \\
\text { every public road. This } \\
\text { control is provided by law } \\
\text { and made every } 2 \text { years. } \\
\text { It is a report consisting in: } \\
\text { the periodical check of the } \\
\text { components that influence } \\
\text { road safety according to the } \\
\text { check framework lists and, } \\
\text { as appropriate, the analysis } \\
\text { of possible effects of the } \\
\text { road repairing works in } \\
\text { course of execution on the } \\
\text { road traffic safety and the } \\
\text { identification of the aspects } \\
\text { related to the prevention } \\
\text { of road accidents (art. 10, } \\
\text { para. } 5 \text { of the Law no. } \\
265 / 2008 \text { ). }\end{array}$ \\
\hline
\end{tabular}




\begin{tabular}{|c|c|c|}
\hline $\begin{array}{c}\text { Evaluation of impact on } \\
\text { road safety, road safety } \\
\text { audit and controls of road } \\
\text { safety }\end{array}$ & The road safety audit & The control of road safety \\
\hline $\begin{array}{l}\text { information that are } \\
\text { necessary to analyze the } \\
\text { cost }- \text { benefit of various } \\
\text { evaluated options. }\end{array}$ & $\begin{array}{l}\text { The report issued } \\
\text { after the evaluation of } \\
\text { impact/road safety audit has } \\
\text { a series of recommendations } \\
\text { regarding the rehabilitation } \\
\text { of the probably observed } \\
\text { deficiencies. }\end{array}$ & $\begin{array}{l}\text { The control report has an } \\
\text { enclosed series of } \\
\text { recommendations and/or } \\
\text { orders regarding the } \\
\text { rehabilitation of possible } \\
\text { deficiencies. } \\
\text { The orders mentioned in } \\
\text { the control report are } \\
\text { obligatory for the authority } \\
\text { that administrates the } \\
\text { controlled roads, in the limit } \\
\text { of established deadlines. }\end{array}$ \\
\hline
\end{tabular}

The series of measures mentioned in the report can be general intervention works executed by the road administration and the deadlines of applying these measures that are set by the Transportation Minister's Order. The evaluation of impact on road safety or the road safety audit are made by auditors or a team of auditors depending on the complexity of control.

Thus, in case of a road accident with dead victims that took place on public roads, police notifies the Road Authority in Romania in $\mathbf{1 5}$ days regarding the accident providing the data in compliance with the law.

In 90 days from notification, the Road Authority in Romania makes an additional check of road safety at the accident place in order to identify possible causes related to infrastructure that led to the accident.

The Road Authority in Romania makes additional checks on the prioritycontrolled roads after the expiration of terms in order to monitor the way of respecting the orders mentioned in the report of road safety control. In the report of road safety additional control, a relevant point is the analysis of possible orders from the periodical/supplementary control reports that were not solved within the established deadline up to the date of accident and that may have been the cause of the accident.
In order to achieve an evaluation of impact on road safety, on road safety audit and road safety control the Road Authority in Romania and the road investor or administrator sign a framework contract.

The road safety audit and road safety control are made in compliance with the principle of transparency, equal treatment and criterion of impartial designation of auditors for road safety respecting the impartial planning along a year.

The Road Authority in Romania designates the auditors and notifies them, the road investor or the road administrator, as appropriate, in the shortest time, but in not more than 30 days from the date of signing the contract.

The road safety auditors cannot refuse the designation only in case of impartial reasons or in one of the situation stipulated by law.

The road safety auditor must inform the Road Authority in Romania about any aware situation that could alter the principle of independence of the auditor towards the investor, designer, contractor or road administrator.

The independence of auditor of road safety towards the investor, designer, executor or road administrator, is altered in the cases shown in the following figure: 


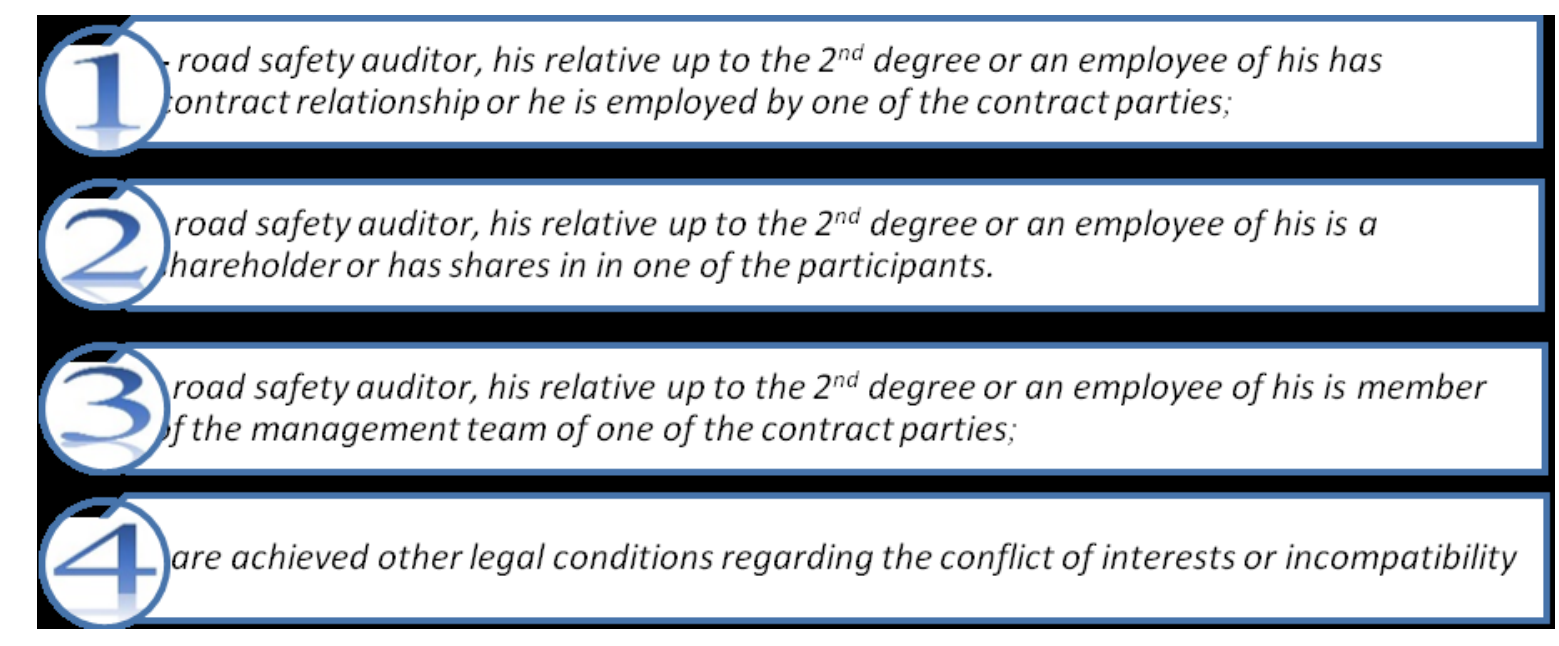

Figure no. 2 The independence of the auditor of road safety towards other persons or situations

In case that one or more auditors make a report of road safety audit/ evaluation of impact on road safety/control on road safety, without respecting the provisions mentioned above, the report is worthless and the auditors of road safety has administrative/civil and/or penal guilt according to the law.

The road investor and administrator must transmit to the Road Authority in Romania the documentation regarding each chapter of the project of road infrastructure or public road that was assessed, controlled or audited in the shortest time, but in not more than 30 days from the date of signing the contract (art 12, paragraph 1 of the Law no. $265 / 2008$ ).

The Road Authority in Romania put at auditor's or auditor team's disposal, at their request, the documentation regarding:

a) evaluation of impact on road safety;

b) documents that are part of prefeasibility, feasibility studies, technical project and details of execution, but not less than: the general plans of the road; the site plans and cross and longitudinal profiles of the road; the plans of fields where the road is built; the plans of horizontal and vertical signalization and the plans of the equipment of smart transport system; the technical reports; the present and future traffic analyses; c) data and information regarding accidents on the audited roads;

d) information regarding recommendations that are part of the prior report;

e) other necessary information.

At the auditor's or team auditors' road safety request, the authorities responsible for road safety put at their disposal, in writing, the necessary information for: the report of evaluation impact on road safety, the road safety audit or control, excepting the cases stipulated by law.

Impact evaluation on road safety and audit are made at the request of the investor addressed to the Road Authority in Romania. The periodical road safety control is made according to an annual planning on the basis of 2 year contracts signed between the administrator of public road and the Road Authority in Romania. The additional road safety control is made when notifying police or according to the own programs of Road Authority in Romania, according to the case (art. 13, paragraph 3 of the Law no. 265/2008).

The report of road safety audit has 4 chapters, one for each stage, each chapter having enclosed a series of recommendations of fixing the possible deficiencies that have been observed.

In case of road safety controls, the report is made in two original copies 
transmitted to both the Road Authority in Romania and road administrator in 90 days at maximum from the date of both the signed contract and the notification.

Within the same deadline, the Road Authority in Romania sends a copy of the road safety report, according to the original one, to the police, too.

The investor must apply the necessary measures in order to respect the recommendations that are part of the report before the end of the stage that is going to be audited or immediately after the conclusions of the final report, or, according to the case, he can oppose to the Commission a part or all the recommendations, sending in writing, the Letter of Appeal in 10 days from the date of receiving the report of road safety audit/evaluation of impact on road safety.

The Commission provides solutions to the letter of objections and can maintain the recommendations, modify them or consider them as not justified. The Commission communicates the result to the investor, the Road Authority in Romania and to the road safety auditor.

The road administrator is responsible for the damage suffered by the road traffic users who were touched by the lack of solution for the obligations contained in the report of road safety control.

The solution of the letter of objections can be opposed in the Contecious Administrative Court. A copy of the final sentence of the Court will be enclosed to the report.
The relationship between the Road Authority in Romania and road safety auditors is set by contract signed by both parties. This contract stipulates the rights and obligations of the parties, the deadlines of finishing and transmission of the reports, the ways of payment according to a framework contract approved by the Minister's of Transportation order.

The Road Authority in Romania makes the classification of roads on criteria of road safety on the basis of periodical analyses of the information from the data basis that is updated each 3 years.

The corrective measures from the report of road safety control, such as recommendations and/or orders, will be focused on the roads stipulated by law. The road administrator will prioritize these measures with the most favorable cost benefit report.

The signalization to warn road users regarding the road works will be made in line with the law in force. They will be visible by day and night and installed at a safe distance according to the rules in force (Tarnu, 2016).

The road users will be permanently informed by the road administrator that there is a road sector with high accident rate or that there are works in course, using adequate ways and/or signalization systems in line with the law regarding public road traffic (The Romanian Government, 1997).

The activities and the elements of impact evaluation of the road safety audit are presented in the fallowing figures. 
Components of the evaluation of impact on road safety:

- definition of the problem;

- present and future situation in case of not initiating any action;

- specific objectives of road safety;

- analysis of impact of proposed alternatives regarding road safety;

- compare options among which there is the analysis of cost - benefit report;

-present all possible solutions

Components that we should have in mind:

- dead victims and road accidents, the objectives of reducing them in comparison with the

scenarios that reveal the lack of initiating actions;

- choose routes and directions;

- possible effects on the existent road networks, such as: exits, lane tunnels, junctions;

-road users including the vulnerable ones (for example: pedestrians, cyclists, motorbikers);

-traffic and its size, clasification and type of the vehicle;

- season and climate conditions;

- sufficient number of zones that allow drivers to stop in safe conditions;

- earthquakes

Figure no. 3 Evaluation of impact on road safety for projects of infrastructure applied in the member states of the European Union (source: adapted from The European Council, 2008)

\section{Applying criteria in the preliminary project stage}

-geographical location (for example: landslide, flooding, avalanche, etc.), season and climate conditions, and earthquake as well.

-junction points and the distance between them;

- number and type of routes;

-type of traffic on the new route;

- functionality of route within the road network;

-weather conditions;

-visibility;

- junction points location;

- means of public transportation and their infrastructures;

-railway level crossing

\section{Applying criteria in the preliminary project stage}

-plan;

- coherent signalisation;

- lighting roads and junctions;

-equipment on the road edge;

-environment specific to road edge and vegetation;

- obstacles installed on the road edge;

-safe parking places;

-vulnerable users of roads (for example: pedestrians, cyclists, motorbikers);

-adjust easily the systems of road restrictions (spaces between lanes, road guardrails to

-avoid the dangers which road users are exposed to)

Applying criteria in the stage of detailed project:

- safety and visibility of road users under various circumstances such as: dark or normal weather conditions.

- readable signalisation signs;

Applying criteria in the stage of the begenning of using roads:

- evaluation of roads from the perspective of the real behavior of road users.

Figure no. 4 Audit operations in the field of road safety regarding projects of infrastructure in the European Union countries 
Being or ceasing to be a road safety auditor is mentioned in the Law no. 265/ 2008 regarding the management of road safety applied to road infrastructure.

Road safety audit and evaluation of impact on road safety are made under free practice regime by the road safety auditors designated by the Road Authority in Romania (art. 5, paragraph 3 of the Law no. 265/2008).

The road safety control is made by the Road Authority in Romania by trained teams of qualified staff employed by the Road Authority in Romania. At least, one member of the team is certified as a road safety auditor.

The road safety auditors employed by the Road Authority in Romania can not make road safety audit and evaluation of impact of road safety.

\section{Conclusions}

The existing black points within the system of management should be revised.
It is vital to develop a program for activities regarding the management of systematical and reoccurring weak points for identification, analysis, identification of measures, set of priorities, effective improvement and evaluation.

The weak points should be identified each year on all roads as the Romanian Police does. The road administrators together with the responsible authorities should get data referring to weak points of the roads they administrate and submit them to analysis.

On the basis of identified weak points, there should be identified measures that could solve the road safety issues, for example physical improvement and not only warning signs located in weak points. The warning signs should be located in weak points only as a temporary measure up to the implementation of an adequate measure.

\section{REFERENCES}

AUSTROADS. (1994). Road Safety Audit, available at: http://www.austroads.com.au/ about-austroads/austroads-guides.

European Commission. (2011). Horizon 2020, available at: http://ec.europa.eu/growth/ sectors/space/research/horizon-2020_ro.

Tarnu, L. I. (2012). Analysis, Investigation and Reconstruction of Road Accidents, Bucharest: Universul Juridic Publishing House.

Tarnu, L. I. (2016). Legal Aspects of Systematization and Signalization of Roads in Romania, Sibiu: „Lucian Blaga” University in Sibiu Publishing House.

The European Council. (2008). The Directive 2008/96/EC, regarding road safety applied to road infrastructure, Bruxelles: The Official Journal of the E.U., L series, no. 319, November, $29^{\text {th }}, 2008$.

The Romanian Government. (1997). Emergency Ordinance no.43 regarding the legal regime of roads, modified and amended by the Law 82/1998, Bucharest: Official Gazette.

The Romanian Government. (2002). Emergency Ordinance no. 195, regarding the traffic on public roads, republished and updated, Bucharest: Official Gazette.

The Romanian Government. (2002). Ordinance no. 1391 for the approval of the Regulation of applying the Government Emergency Ordinance no.195/2002, regarding the traffic on public roads, republished and updated, Bucharest: Official Gazette.

The Romanian Parliament. (2008). The Law no. 265, republished, regarding the road safety applied to road infrastructure, Bucharest: Official Gazette.

The Romanian Parliament. (2014). The Penal Code of Romania, Bucharest: Official Gazette.

The Romanian Parliament. (2016). National Strategy of Road Safety for the period 2016-2020, Bucharest: Official Gazette. 